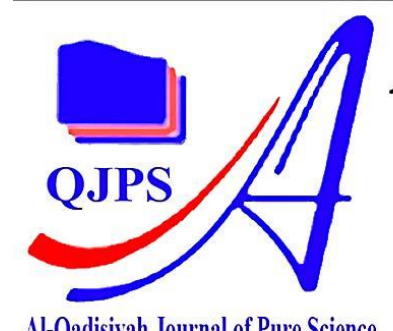

Al-Qadisiyah Journal of Pure Science

ISSN(Printed): 1997-2490

ISSN(Online):

$2411-3514$

DOI : /10.29350/jops.

http://qu.edu.iq/journalsc/index.php/JOPS

\title{
Prevalence Comparsion between Typhoid Fever and H. pylori Bacteria in Al-Diwaniyah Province
}

\section{Authors Names \\ a. Mujj Jaafer Douhan \\ b. Khadeeja Abees Hmood \\ Article History}

Received on: $12 / 10 / 2021$

Revised on: 8/11/2021

Accepted on: $10 / 11 / 2021$

Keywords:

H. pylori, Typhoid fever, blood parameter, Trace elements, $\mathrm{Zn}, \mathrm{Cd}, \mathrm{Cu}$

DOI: https://doi.org/10.29350/ jops.2021.26. 5.1457

\section{ABSTRACT}

Background: Salmonella, which causes typhoid fever, is one of the most common bacteria worldwide transmitted through contaminated food and water, causing infection in the digestive system, as well as H.pylori, which has a general Prevalence rate, causing Stomach ulcers and Stomach cancer, and has effects on blood picture and elements in Serum Blood ( $\mathrm{Zn}, \mathrm{Cu}, \mathrm{Cd}$ ) according to the current study.

method: The study was conducted in Al - Diwaniyah province hospitals and Laboratories, and different measurement methods were adopted. For typhoid fever, it was measured by the widal test, while $\mathrm{H}$. pylori the method of rapid later at chromatography was used, and the blood picture by ( $\mathrm{CBC}$ ) device and trace elements by Atomic Absorption Spectrophotometer ( AAS ).

Results: The incidence of typhoid fever is higher than $\mathrm{H}$. pylori $(77.41 \%),(60 \%)$ respectively, age (typhoid , 31-40) (90\%), H. pylori ( 41-50 ) (83.33\%), and gender (Typhoid, in female ( $79.38 \%$ ), H. pylori in male ( $73.70 \%$ ), and number of family, (Typhoid and H. pylori in family more than individual , ( $86.79 \%),(73.33 \%)$, Residential area in rural area for both ( $77.65 \%),(86.36 \%)$, and drinking water uses filter water for both ( $92.70 \%$ ), (73.07\%), and mon the of Study ( typhoid in May , Jane, July, H. pylori in November, March , April , June ) , and economic status ( Typhoid in good incomes ( $86.15 \%$ ) , H. pylori, low incomes ( $92.30 \%$ ) , blood parameter (Typhoid increase in ( RBC , MCV ), decrease in ( $\mathrm{Hb}, \mathrm{WBC}, \mathrm{LYM}, \mathrm{PLT}$ ), $\mathrm{H}$. pylori increase ( RBC ), decrease in ( $\mathrm{Hb}$, WBC , MCV , LYM , PLT ) , Trace element increase in $(\mathrm{Cu})$ and decrease in $(\mathrm{Zn}, \mathrm{Cd})$ for both.

Objectives: This study was carried out to determine the prevalence of typhoid fever compared with $\mathrm{H}$. pylori, and effect the disease on blood picture and trace elements. 


\section{Introduction}

The bacterium Helicobacter pylori is one of the most prevalent bacterial infections in humans, and it has numerous ways to colonize the host. Flagella mediated motility, ability to survive in an acidic Stomach environment adhesions to host receptors, and toxin release that causes tissue damage. Gastritis peptic ulcer, disease, gastro duodenal ulcer, atrophic gastritis, gastric malignancies, and other conditions are all caused by it [1]. And it's a global public health problem affecting both developed and developing countries [2]. About 4.4 billion individuals were infected globally with H .pylori during 2015 increasing with age and Socioeconomic status, and geographical area [3].

furthermore, previous research has linked $\mathrm{H}$. pylori infection to a variety of hematological symptom [4], and cause changes in the patient complete blood picture and effects on red blood cells, hemoglobin Concentration, hematocrit, average Cell and platelets [5], and also the trace elements in the blood Serum are affected by Helicobacter pylori infection, and differences in Some element levels are linked to the occurrence of stomach cancer Many studies also aimed to Study the levels of trace elements for patients with $\mathrm{H}$. pylori and Camper them with healthy people, and the results showed that some Studies have high percentage and other decrease, and Studies have not shown significant different in the level of elements [6].

Salmonella infection are the most prevalent food-borne diseases, and they continue to be a major public health concern around the world, particularly in developing nations Typhoid fever caused an estimated 21.7 million illnesses and 2.17.000 fatalities peryer, according to the WHO 2000 census The management of typhoid fever has improved with the development of better diagnostic and therapeutic technologies [ 7-8] Typhoid fever is a systemic bacterial infection caused by gram negative rods, such as Salmonella typhi, and spread by ingesting water or food Contaminated by infected carriers urine or feces. Typhoid fever primarily affects children and young adults and is a leading source of morbidity around the world [ 9 ],poor sanitation and poor hygiene and contaminated water, food and drinks purchased from Street vendors, that is a common risk factors lead to an epidemic [10 ].

And the Typhoid fever has significant effect on some hematological parameters, but these changes can aid in diagnosis. and treatment [11]. And also typhoid fever contribute with trace elements in serum blood and can cause special changes in the concentration of trace elements, like Zink and copper etc.[12]. The current study aims to compare The prevalence rate between $\mathrm{H}$. pylori and typhoid fever infection by type of infection, age, gender, number of family members, family monthly income, area of residence, drinking water quality, and months of the study year in addition to measuring the values of hematological parameters and concentrations of trace elements for infected patients and comparing them with healthy subjects.

\section{Methods}

\subsection{Data Collection}

367 blood Samples were connected and examined (10 healthy people, 186 infected with typhoid fever, $171 \mathrm{H}$. pylori). The number of infected with typhoid fever was (45) and $\mathrm{H}$. pylori were ( 27 ), of the Patients who came to some public hospitals and private Lab orator of the center, districts and 
districts of Diwaniyah province, and the ages included (1-70) years and for the period from $(1 / 11 / 2020)$ to $(1 / 7 / 2021)$.

\subsection{Separation of Samples}

After blood was drawn from infected people by using $5 \mathrm{~mL}$ medical syringe, $2 \mathrm{~mL}$ was placed in a tube containing EDTA for the purpose of blood picture tests [ hemoglobin ( $\mathrm{Hb}$ ), red blood cells (RBC), white blood cells (WBC), lymphocytes (LYM), hematocrit (MCV), platelets (PLT)], and 3mL was placed in a normal test tube and left vertically in the tube holder for (10-15) minutes, then was centrifuged at a speed of 3000 then the serum was separated by pipette and the sediment was discarded, and the serum for the purpose of measuring the Concentration of trace element [ Zinc (Zn), Copper (Cu), Cadmium (Cd) ]

\subsection{Samples examination}

\subsubsection{H. pylori examination.}

The Rapid Lateral immune chromatography Assay method used, which depends on the serum blood examination to confirm infection, which is done by using a strip containing chromatographic paper and covered with anti-bacterial antibodies at the reaction Site, after the blood is drawn from the patient from ( $3-5 \mathrm{~mL})$ and after Completing the endoscopy examination and then it is separated from the body by centrifugation at a speed of 3000 revolution 1 minutes, for a period of 10 minutes, one or two drops of Serum are placed in the tape or cassette, The tape is raised to the top and knocked once or twice and then read the result after 10 minute If one red line appears, the result is negative, and if two lines appear, the result is positive

\subsubsection{Typhoid fever examination.}

Salmonella is examined using the Widal method, which is carried out using four reagents, which help in the appearance of granulation in the presence of salmonella bacteria. After drawing the blood from the patient and separating it from the serum, we prepare a slide, and prepare reagents at room temperature and through a pipette we put a drop of Serum + type reagent O, and Second drop of serum + type reagent $H$. and third drop of Serum +type reagent $A H$, and fourth drop of serum + type reagent $\mathrm{BH}$, that is, we have four drops along the slide and we move them with stick and then in a circular motion as well, and leave them for 10 minutes until the appearance of graininess, and the result is positive.

\subsubsection{Blood parameter examination}

done by used blood cell a count ( $C B C$ ), It has advanced specifications and gives high accuracy in measuring the parameters, as it measures the blood parameters through its part, and after placing the blood in a test tube containing (EDTA).

\subsubsection{Trace elements examination}

The trace elements ( zinc, copper, cadmium) were measured using atomic absorption Spectrophotometer (AAS) and based on the blood serum to the trace elements concentrations.

\subsection{Statistical analysis}

The Statistical program SPSS version 27 was used for the purpose of reading the results Statistically and to find out the significant differences between the variables included in the Study. The one way ANOVA test was used with calculating the value of the least significant difference LSD, to compare 
the averages of blood standards and levels of minerals in the blood of the experiment groups the percentages were also compared by calculating the value of the chi-square $x^{2}$, and the differences were issued at a probability level of $5 \%$ [13].

\section{Results}

The results of the current study showed the highest prevalence rate recorded for typhoid fever by (77.41\%), while the prevalence of $\mathrm{H}$. pylori bacteria was recorded (60\%). Table (1) showed the highest infection rate for the age group (31-40) years and it reached (90\%) for fever Typhoid had the lowest infection rate for the group (51-60) years, and its rate was (62.96\%), while the highest infection rate for $\mathrm{H}$. pylori disease was recorded in the age group (41-50) years and it reached (83.33\%), and the lowest infection rate for the group (10-20) years was (28.57\%) ،Table (2) indicates that the infection rate in females is higher than males and it reached (70.38\%) for typhoid fever, while H. pylori bacteria infection rate in males is higher than females and it reached (73.07\%), while Table (3) shows the highest infection rate in the families with more than 9 members reached $(86.79 \%)(73.33 \%)$ for typhoid fever and $\mathrm{H}$. pylori bacteria respectively, and the lowest infection rate in the family (5-3) individuals amounted to (68.57\%) (43.75\%) for typhoid fever and $\mathrm{H}$. pylori bacteria respectively،Table (4) indicated the quality of the water used for drinking, and showed the highest rate of infection for users of filtered water for both diseases, typhoid fever and $\mathrm{H}$. pylori bacteria, and it reached $(92.70 \%)$ (73.07\%), respectively, and Table (5) indicated the highest infection rate in rural areas for both diseases. Typhoid fever and $\mathrm{H}$. pylori bacteria reached (77.65\%) (86.36\%), respectively, and table (6) showed the highest infection recorded for people with good incomes of typhoid fever, which amounted to $(86.15 \%)$, while $\mathrm{H}$. pylori bacteria had the highest infection recorded for people with low incomes, which amounted to (92.30\%)6Table (7) showed the prevalence of typhoid fever increased in the month (May, June, July)/2021, and the infection rate was (94.73\%) (94.44\%), respectively, while $\mathrm{H}$. pylori infection rate increased in November 2020, March and April and June / 2021 , and the infection rate was (75\%) for each of them.

While Table (8) showed a difference in the blood parameters values of typhoid and $\mathrm{H}$. pylori infected patients compared with the healthy controls, the values (RBC), (MCV) reached $(4.52 \pm 0.41) 10^{6} / \mu \mathrm{l},(85.44 \pm 3.54) \mathrm{fl}$, respectively, compared with. The healthy subjects $(3.52 \pm 0.11) 10^{6} / \mu \mathrm{l},(81.66 \pm 2.62) \mathrm{fl}$, while the values of $(\mathrm{Hb}),(\mathrm{WBC})(\mathrm{LYM}),(\mathrm{PLT})$ decreased and amounted to $(12.9 \pm 0.92) \mathrm{g} / \mathrm{dl},(9.72 \pm 0.66) 10^{3} / \mu \mathrm{l},(24.28 \pm 1.02) \%,(316.2 \pm 9.38) \% \mathrm{P}$ respectively compared to healthy controls $(17.34 \pm 0.61) \mathrm{g} / \mathrm{dl},(3.52 \pm 0.11) 10^{6} / \mu \mathrm{l},(33.34 \pm 0.74) \%$, (316.2 \pm 9.38$) \%$. While $H$. pylori showed an increase in RBC values $(4.68 \pm 0.65) 10^{3} / \mu \mathrm{l}$, compared with healthy controls, where the values of (Hb), (WBC), (LYM), (MCV), (PLT) decreased, It was $(12.85 \pm 2.01) \mathrm{g} / \mathrm{dl},(8.26 \pm 1.13) 10^{3} / \mu \mathrm{l},(29.99 \pm 1.63) \%$, (77.6 \pm 2.78$) \mathrm{fl},(287.5 \pm 5.71) \%$, when compared with healthy controls.

Table (9) shows the concentrations of trace elements for patients with typhoid and H. pylori bacteria compared with the healthy controls, where the copper concentration increased for both typhoid fever and $\mathrm{H}$. pylori diseases and reached $(2.42 \pm 0.66) \mu \mathrm{g} / \mathrm{dl},(2.12 \pm 0.52) \mu \mathrm{g} / \mathrm{dl}$, respectively compared. With healthy controls $(1.51 \pm 0.62) \mu \mathrm{g} / \mathrm{dl}$, zinc and cadmium concentrations decreased for typhoid fever and reached $(0.776 \pm 0.22) \mu \mathrm{g} / \mathrm{dl},(0.011 \pm 0.01)$ compared to healthy controls $(1.185 \pm 0.30) \mu \mathrm{g} / \mathrm{dl},(19.793 \pm 6.12)$, respectively. While $\mathrm{H}$. pylori bacteria, the concentrations of zinc and cadmium reached $(0.755 \pm 0.17) \mu \mathrm{g} / \mathrm{dl}$ and $(0.023 \pm 0.01) \mu \mathrm{g} / \mathrm{dl}$, respectively. 
Table(1) Showed the age of typhoid and H. pylori

\begin{tabular}{|c|c|c|c|c|c|c|}
\hline \multirow[t]{2}{*}{ Age } & \multicolumn{3}{|c|}{ Typhoid fever } & \multicolumn{3}{|l|}{ H. pylori } \\
\hline & $\begin{array}{l}\text { Checked } \\
\text { number }\end{array}$ & $\begin{array}{l}\text { Infected } \\
\text { number }\end{array}$ & $\%$ & $\begin{array}{l}\text { Checked } \\
\text { Number }\end{array}$ & $\begin{array}{l}\text { Infected } \\
\text { number }\end{array}$ & $\%$ \\
\hline$(10-20)$ & 48 & 36 & $75 \%$ & 7 & 2 & $28.57 \%$ \\
\hline$(21-30)$ & 30 & 28 & $87.5 \%$ & 9 & 4 & $44.44 \%$ \\
\hline$(31-40)$ & 36 & 27 & $90 \%$ & 10 & 8 & $80 \%$ \\
\hline$(41-50)$ & 24 & 21 & $87.5 \%$ & 12 & 10 & $83.33 \%$ \\
\hline$(51-60)$ & 27 & 17 & $62.96 \%$ & 4 & 2 & $50 \%$ \\
\hline$(61-70)$ & 21 & 15 & $71.42 \%$ & 3 & 1 & $33.33 \%$ \\
\hline Total & 186 & 144 & $77.41 \%$ & 45 & 27 & $60 \%$ \\
\hline$x^{2}$ & 8.3 & & & 0.006 & & \\
\hline$P$ value & 0.140 & & & 0.937 & & \\
\hline
\end{tabular}

Table (2) Showed type of sex for typhoid fever patient and H. pylori

\begin{tabular}{|c|c|c|c|c|c|c|}
\hline Sex & Typhoid f & & & H. pylori & & \\
\hline \multirow{3}{*}{ Male } & Checked & Infected & $\%$ & Checked & Infected & $\%$ \\
\hline & Number & Number & & Number & number & \\
\hline & 89 & 67 & $75.28 \%$ & 26 & 19 & $73.07 \%$ \\
\hline Female & 97 & 77 & $79.38 \%$ & 19 & 8 & $42.10 \%$ \\
\hline Total & 186 & 144 & $77.41 \%$ & 45 & 27 & $60 \%$ \\
\hline$x^{2}$ & \multicolumn{3}{|l|}{0.446} & \multicolumn{3}{|l|}{7.43} \\
\hline $\mathrm{P}$ value & \multicolumn{3}{|l|}{$0.504^{*}$} & \multicolumn{3}{|l|}{0.006} \\
\hline
\end{tabular}

Table (3) Showed number of family for typhoid fever and H. pylori

\begin{tabular}{|c|c|c|c|c|c|c|}
\hline \multirow{3}{*}{$\begin{array}{l}\text { Number } \\
\text { of family }\end{array}$} & \multicolumn{3}{|c|}{ Typhoid fever } & \multicolumn{3}{|l|}{ H. pylori } \\
\hline & Checked & Infected & $\%$ & Checked & Infected & $\%$ \\
\hline & Number & number & & Number & number & \\
\hline$(5-3)$ & 70 & 48 & $68.57 \%$ & 16 & 7 & $43.75 \%$ \\
\hline$(8-6)$ & 63 & 50 & $79.36 \%$ & 14 & 9 & $64.28 \%$ \\
\hline$(>9)$ & 53 & 46 & $86 \%$ & 15 & 11 & $73.33 \%$ \\
\hline Total & 186 & 144 & $77.41 \%$ & 45 & 27 & $60 \%$ \\
\hline$x^{2}$ & 2.46 & & & 2.97 & & \\
\hline$P$ value & $0.292^{*}$ & & & 0.226 & & \\
\hline
\end{tabular}

Table (4) Showed the type of water drinking for typhoid fever and H.pylori

\begin{tabular}{|c|c|c|c|c|c|}
\hline \multirow[t]{3}{*}{ Type of water } & \multicolumn{2}{|l|}{ Typhoid fever } & \multicolumn{3}{|l|}{ H.pylori } \\
\hline & Checked & $\%$ & Checked & Infected & $\%$ \\
\hline & Number & & Number & number & \\
\hline
\end{tabular}




\begin{tabular}{lllllll}
\hline RO & 90 & 55 & $61.11 \%$ & 19 & 8 & $42.1 \%$ \\
\hline filter water & 96 & 89 & $92.70 \%$ & 26 & 19 & $73.07 \%$ \\
\hline Total & 186 & 144 & $77.41 \%$ & 45 & 27 & $60 \%$ \\
\hline $\mathrm{X}^{2}$ & 144 & & & 4.38 & & \\
\hline P value & $26.520^{*}$ & & & $0.036^{*}$ & & \\
\hline
\end{tabular}

Table (5) Showed the Residential area for typhoid fever and H.pylori

\begin{tabular}{lllllll}
\hline Residential area & \multicolumn{3}{l}{ Typhoid fever } & \multicolumn{3}{l}{ H.pylori } \\
\cline { 2 - 6 } & $\begin{array}{l}\text { Checked } \\
\text { Number }\end{array}$ & $\begin{array}{l}\text { Infected } \\
\text { number }\end{array}$ & $\%$ & $\begin{array}{l}\text { Checked } \\
\text { Number }\end{array}$ & $\begin{array}{l}\text { Infected } \\
\text { number }\end{array}$ & $\%$ \\
\hline City center & 92 & 71 & $77.17 \%$ & 23 & 8 & $34.78 \%$ \\
\hline $\begin{array}{l}\text { Districts and } \\
\text { sub-Districts }\end{array}$ & 94 & 73 & $77.65 \%$ & 22 & 19 & $86.36 \%$ \\
\hline Total & 186 & 144 & $77.41 \%$ & 45 & 27 & $60 \%$ \\
\hline $\mathrm{X}^{2}$ & 0.006 & & & 12.46 & & \\
\hline P value & $0.937^{*}$ & & & $0 *$ & & \\
\hline
\end{tabular}

Table (6) Showed the Economic status for typhoid fever and H.pylori

\begin{tabular}{lllllll}
\hline $\begin{array}{l}\text { Economic } \\
\text { status }\end{array}$ & \multicolumn{2}{l}{ Typhoid fever } & \multicolumn{3}{l}{ H.pylori } \\
\cline { 2 - 6 } & $\begin{array}{l}\text { Checked } \\
\text { Number }\end{array}$ & $\begin{array}{l}\text { Infected } \\
\text { number }\end{array}$ & $\%$ & $\begin{array}{l}\text { Checked } \\
\text { Number }\end{array}$ & $\begin{array}{l}\text { Infected } \\
\text { number }\end{array}$ & $\%$ \\
\hline Low & 60 & 43 & $71.66 \%$ & 13 & 12 & $92.30 \%$ \\
\hline Mediat & 61 & 45 & $73.77 \%$ & 15 & 10 & $66.66 \%$ \\
\hline Good & 65 & 56 & $86.15 \%$ & 17 & 5 & $29.41 \%$ \\
\hline Total & 186 & 144 & $77.41 \%$ & 45 & 27 & $60 \%$ \\
\hline$X^{2}$ & 4.43 & & & 12.55 & & \\
\hline P value & $0.109 *$ & & & $0.002^{*}$ & & \\
\hline
\end{tabular}

Table (7) Showed Months of study year

\begin{tabular}{|c|c|c|c|c|c|c|}
\hline \multirow{2}{*}{$\begin{array}{l}\text { Months of study year } \\
1-\quad \text { October } 2020\end{array}$} & \multicolumn{3}{|c|}{ Typhoid fever } & \multicolumn{3}{|c|}{ H. pylori } \\
\hline & 19 & 10 & 52.63 & 6 & 2 & 33.33 \\
\hline 2- $\quad$ November2020 & 18 & 11 & 61.11 & 4 & 3 & 75 \\
\hline 3- December 2020 & 19 & 11 & 57.98 & 4 & 2 & 50 \\
\hline 4- January 2021 & 19 & 10 & 57.89 & 5 & 3 & 60 \\
\hline
\end{tabular}




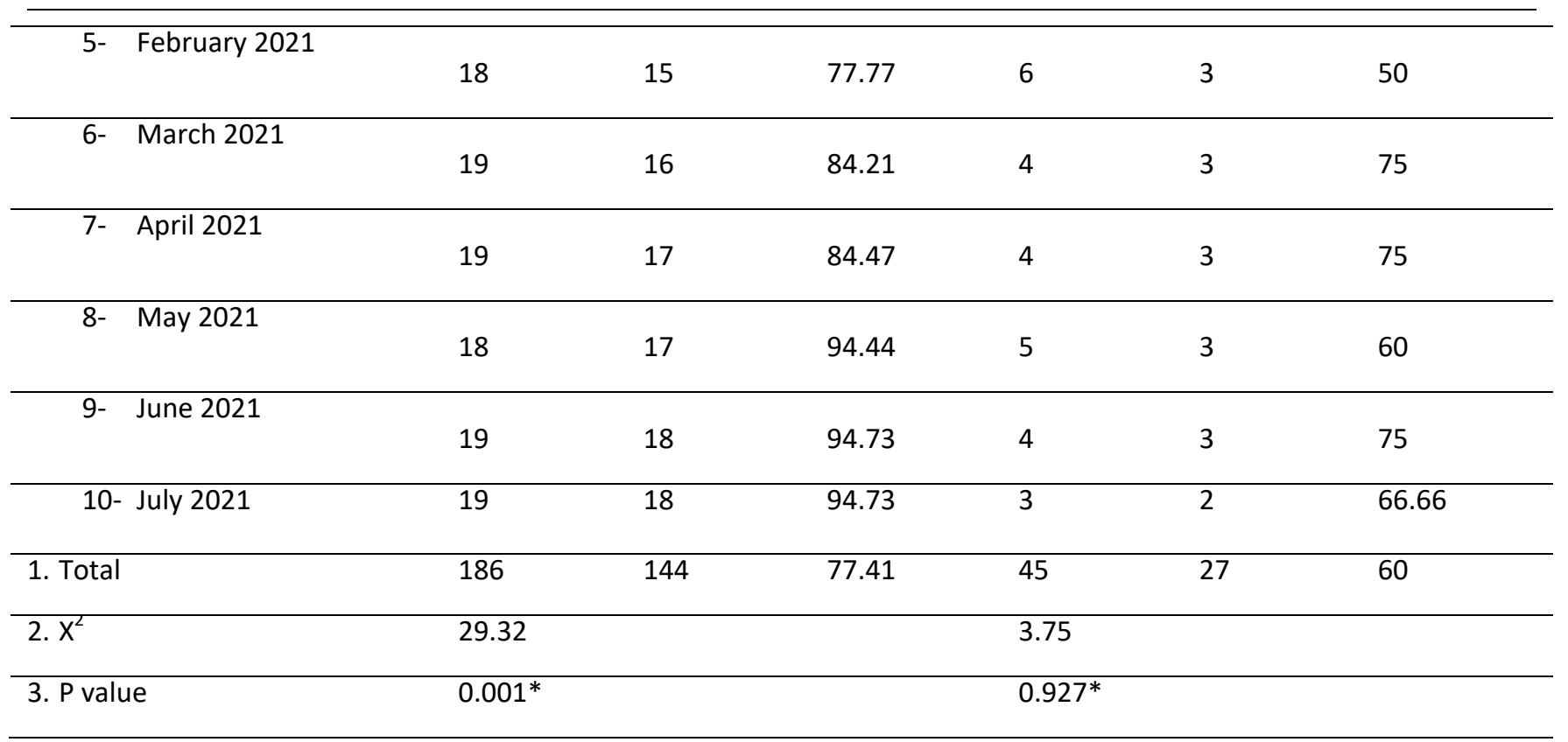

Table (8) showed Blood parameter for typhoid and H. pylori Compared for Healthy people

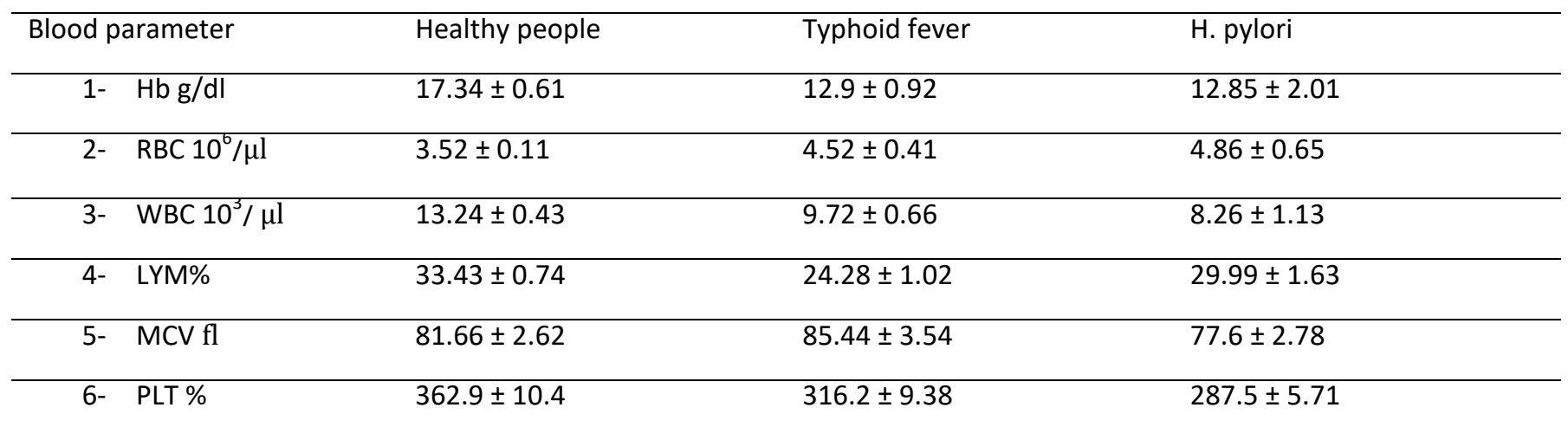

Table (9) Showed Trace elements value for both typhoid fever and H. pylori

\begin{tabular}{llll}
\hline Trace elements & Healthy people & Typhoid fever & H. pylori \\
\hline $1-\mathrm{zn}$ & $1.185 \pm 0.30$ & $0.776 \pm 0.22$ & $0.755 \pm 0.17$ \\
\hline 2 -cu & $1.51 \pm 0.62$ & $2.42 \pm 0.66$ & $2.12 \pm 0.52$ \\
\hline 3-cd & $19.793 \pm 6.12$ & $0.011 \pm 0.01$ & 0.23 .01
\end{tabular}

\section{Discussion}

The current study showed that the prevalence of typhoid disease is higher compared to H. pylori bacteria, and the reason is attributed to transmission through contaminated food and water, to the health and environmental situation, as well as general hygiene and to the standard of living, social and economic, which increases the chances of its spread 'Also the highest infection appeared for the 
age group (31-40) years, and the infection was more in females than in males, and the reason may be attributed to direct contact with the source of infection for females more, and it agrees with the study [14]. In addition, the highest rate of infection was recorded in rural areas, due to the lack of cultural awareness in these areas, poor public and personal hygiene, or it may be the result of eating poorly cooked food, and unwashed fruits and vegetables well. and the highest rate of infection was recorded in the summer months (May, June, and July), and the reason is due to the result of the activity of salmonella bacteria in the summer, which leads to the chance of its spread more and this result agrees with the study [14-15].and The highest infection rate appeared for users of household filtered water, indicating that salmonella bacteria are transmitted through the water and are characterized by a longer stay in the water, and that household filtered water is not the best for drinking, so it is necessary to rely on more pure, safe and drinkable water, and this agrees with a study [16].The reason for the emergence of the highest incidence of infection in the most 9-member families is due to direct contact with the patient as a result of crowding within the family, which increases the chance of transmission more easily, in addition to using the same common tools, which may be contaminated. This also helps in the transmission of the disease within the family, and agree. This is with a study [17].The highest rate of infection appeared for people with good income and it does not agree with the study [18] which showed the highest rate of infection for people with low income, and the reason is attributed to their dependence on restaurant food as a result of their work outside the home that forces them to eat outside the home. As for $\mathrm{H}$. pylori bacteria, the highest infection rate was recorded for the age group (41-50 years) and it agrees with the study [19-20]. The reason for this is that $\mathrm{H}$. pylori bacteria become active and exacerbate with age, as the study showed that the infection increases in males more of females, and the reason was attributed to the fact that women take antibiotics during their lifetime (pregnancy or childbirth) that may inhibit the action of these bacteria. The highest rate of infection was also recorded in rural areas, and this study does not agree with the study [21], as for the months of the year, the highest rate of infection was recorded in the months (November, March, April, and June), and it does not agree with the study [22], which showed the rainy months more An infection from the summer months, and the reason may be attributed to the fluctuation of factors that stimulate the activity and growth of $\mathrm{H}$. pylori bacteria, its transmission and spread،It also showed the infection rate of people dependent on household filtered water, and this reflects the chance of transmission through water contaminated with the feces of patients infected with $\mathrm{H}$. pylori bacteria, and this was confirmed by [23] that is transmitted through wastewater as a result of not being treated accurately. Also, the number of casualties increased for people with low incomes, and the reason was due to the determination to provide sufficient means, whether it was food or medical, in addition to the general and personal hygiene caused by the lack of cultural awareness. In addition, the infection rate increased in families with more than 9 members, and it is consistent with [24].

As a result of crowding within the family and direct contact with the patient, it may pass from the mother to her child during breastfeeding, in addition to the use of shared tools.

As for blood parameters, many vital indicators have become dependent on $C B C$ measurement in recent years, and they are widely used in many areas because of their ease and low cost, so many doctors can use them in practice [25] where blood standards play many warning signs. The results of the current study showed a difference in the values of the blood parameters, and showed a decrease in the values of (Hb, RBC, LYM) for typhoid disease and the same values increased in bacterial $\mathrm{H}$. pylori disease compared to healthy controls, while the values of (WBC, MCV, PLT) 
decreased for H.pylori disease and increased for typhoid disease compared to healthy controls. These results do not agree with the study [5]. Concerning the trace elements, it showed an increase in copper concentrations for typhoid and H.pylori disease and a decrease in zinc and cadmium concentrations. These results are consistent with the study [26], and not consistent with the study [27].

\section{References:}

[1] Abdulaziz S.M. Typhoid fever: Vaccines and the diagnostic value of widal test in Basrah community ( Msc . the Sis ). Coll of Med Univ- of Basrah- 1986

[2] Ahmed mohammed Elnour Elkhalifa Abdelhadi M. Agena, Abdelhakam G. Tamomh, Areej F.A. Hassan, Fatima M.H - Albasheer, Sakna G.K. Omer, Anass H.Albasheer Abozar Y. Elderdery. complete Blood Counts among chronic patients of Hilecobacter pylori infection 2021.

[3] Ali Hassan Abro, Ahmed Ms Abdou Jawahar L, Gangwani , Abdulla M Ustadi, Nadeem J Younis, Hina Seyada Hussaini. Hematological and Biochemical changes in typhoid fever

[4] Ali Hassan Abro, Ahmed MS Abdou, Jawahar L, Gangwani , Abdulla M UStadi, Nadeem J Younis, Hina Seyada Hussaini Hematological and Biochemical changes inty phoid fever. Pakistan Journal of Medical sciences 2009; Vol 25 ( 2 ) : 166-171

[5] Anl a Hu. Lili chuanlai Hu. Daoming Zhang. chen wang. Yan Jiang. Meng Zhang. chunmei Liang. Wenjun chen. Qinjli Bo. Qihong Zhao. 2018. Serum Concentration of 15. elements Among Helicobacter pylori. Infected Resident. from Lujian County with High Gastric Cancer Risk in Estern china.

[6] Anla Hu Lili. chuanlai Hu Daoming zhang chen wang. Yau Jiavg Meng zhang. chunmei hiang. Wenjun chen Qihong Zhao , 2018 , Serum concentration of 15 elements Among Helicobacter pylori Infected Residents from Lujiang county . with high Gastric cancer Risk in Eastern china .

[7] Brown LM , ( 2000 ) Helicobacter pylori , Epidemiology and routes of transmission Journal Epidemiol - Rev.,vol22: pp - 238- 297

[8] Campuzano - Maya G. Hematological manifestations of Helicobacter pylori infection. world journal of gastroenterology: WJG. 2014 sep 28; 20 ( 36 ) : 12818

[9] Crump JA , Luby Sp, Mint ZED . The global burden of typheid fever. Bull world Health organ 2004; 82:346-53.

[10] Chmiela M, kupcinskas J. Review: Pathogenesis of Helicobacter pylori, infection. John wiley. 2019,-24:1-5.

[11] Dangana A, Ajobiewe J , Nuha A. Haematological changes associated with Salmonella paraty phi in humans. International Journal of Biomedical and Health Sciences 2010; V016 (4): 219-222)

[12] Fauci As, Loscalzo J, Kasper DL, Hauser SL, Longo DL , Jameson JL Harrison's principles of internal medicine 18th ed- New York : Mc Graw Hill; 2012. p . 1275.

[13] Hooi JKY, Lai WY, Ng wK,etal . Global prevalence of Helicobacter pylori Infection: systematic Review and meta-Analysis - world J of Gastroenterology. 2017, 153 (2): 420-46 doi : 10.1053 / j. gastro. 2017-04-022.

[14] Ina S Santos , Jose Boccia , Ari San tos Neiva CJ valle Camila s Halal, Marta Colvara Bachilli , and Ricardo D Lopes perevalence of Helicobacter pylori, infection and associated factors among a dalts in Southern Brazil a population - based cross - sectional study.

[15] Mahmoud N. Al - Khushali, Azhar N. Al khafaji, Zainab k . AL azzawe . Typhoid and paratyphoid fever in children in kadhimiya Hospital ( 2007 ).

[16] M. dela Luz Alvarez, fanny wargaft, Julio Espinoza, Magdalena Araya, Guillermo 1992. Hygiene habits and carriers in families with a child who has had typhoid fever .

[17] Ma. victoria O, Espaldon, Jesasitao . Coladilla, Ricac, Ancog . Sue Lizac Saguiguit , Marya layao. Espalden and Zenaida M. Sumalde. 2008 Valuation of Socio - economic and Health Impacts of Typhoid outbreak in calamba city, Laguna province.

[18] Mohammed Hay der Musa , Jihan Nocle Hussein , 2016, avaluation of socio economic factors Related to helicobacter Pylori Infection in Duhok city.

[19] MARA G - Daminguez- bello . bernardo beker, moises guelrud, Jorge vivas. Simon Peraza. 2002, Short report: socio economic and Seasonal variations of helicobacter pylori infection in patients in Venezuela. 
[20] ozougwu, J.C. obiukwu, C.E, obimba , K.C. Elom , M.O, Usanga , V . U , Haematological changes Associated with male and female typhoid fever patients ( 2016 ).

[21] pakistan Journal of Medical Sciences 2009 ; Vo 125 ( 2 ): 166-171

[22] Patrizia Dominici, Stefano Bellentani, Anna Rita Di Biase, Gioconda Sacco celo, Aurelia Le Ruse, Flora Masutti, Laura Viola , Fiorella Ball, Claudio Tiribelli, Roberto Grilli Michele Fasilla , Enzo Grossi, 1999, familal Clustering of Helico bacter pylori infection population based study.

[23] Rocha AM,BotelhoLF,Rocha DM(2014)Improvment of thrombocytopenia after treatment for Heliconacter pylori in patient with immunologic thrombocytopenic purpura.Rev Bras Hematol Hemoter 36: 162-164

[24] Robert S. pekarek , R . M, kluge,LHL Dupont,R .W. Wanne macher, Jr., R.B. Hornick, K.A. Bostian, and W.R, Beisel. Serum zinc, iron , copper, Concentrations during Typhoid fever in man: effect of chloramphenicel Therapy.

[25] Shilpa v . Vplaankar, Syeda Heena . kauser , Mandakini B. Tengli , 2014 , Haematological profile in typhoid fever

Schiefer , w , C. (1980). Statistics for the biological sciences $2^{\text {nd }}$ ed Addison Wesley publcomp, California , London.

[26] Saleh Nazmy Mwafy, wesam mohammad A Fana, 2017, Hematological parameters, Serum iron and vitamin $B_{12}$ levels in hospitalizations palstinian adult patients infected

[27] vikbladh L, Studies on zink in blood. Scand . J. Clin - Lab. Invest (Suppl. 2 ) 3,1 ( 1951). 